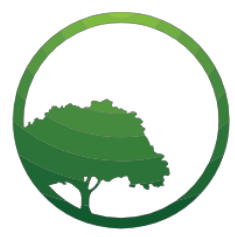

Business \& Social Science IJRBS

\section{Research in Business and Social Science}

IJRBS Vol 8 No 2, ISSN: 2147-4478

Contents available at www.ssbfnet.com/ojs

\title{
The Impact of Internal Control on the Profitability of Microfinance Institutions in Senegal
}

\section{Gnilane Ndiaye}

Corresponding Author: School of Managemet, Hefei University of Technology, China

\section{Cheng BO}

School of Managemet, Hefei University of Technology, China.

\section{Azenga V.V.}

School of Managemet, Hefei University of Technology, China

\section{Juniter K.M}

School of Managemet, Hefei University of Technology, China

\begin{abstract}
This study sought to establish the relationship between internal control and profitability of the Microfinance Institutions in Senegal. The study utilizes a survey design to sample $118 \mathrm{MFI}$ 's to address three objectives namely: To establish the influence of internal control on Earnings Per Share, (EPS) of MFl's, To establish the influence of internal control on Return On Assets (ROA), The influence of internal control on return on Equity (ROE), and finally, the influence of internal control on profit margin of MFI's. The study utilized multiple regression analysis to analyses quantitative data collected from the MFl's and the hypothesis was tested at $95 \%$ confidence interval. The study found out that all dimensions of internal control were positively and significantly associated to the four indices of profitability of MFI's in Senegal. The study recommends that the government of Senegal issues a rational policy framework to ensure all MFIS comply with the provisions of the Senegalese Central Bank on internal controls systems of all financial institutions in the country.
\end{abstract}

Key words: Earnings per Share, Return on Assets, Profit Margin, Return on Equity, Internal Control JEL classification: $G 10$ Submitted: 14.01.2019 - Accepted: 11.13.2019

\section{Introduction}

Internal control of an organization's structure is the work and authority flows, people and management of information systems which is designed to help the organization accomplish its goals and objectives. The 
objectives of internal control of an organization are related to the reliability of the financial reporting, feedback on time which show the achievement of strategic operational goals(Kieso, Weygandt, \& Warfield, 2010). Management has three objectives that guide the designing of an effective internal control system, (McPeak, Pincus, \& Sundem, 2012).

it is entirely responsible for preparing financial statements for investors, creditors and other users. The second objective of an internal control system is to encourage efficiency and effectiveness of operations that is effective use of resources. Lastly the internal control encourages compliance with laws and regulations. The performance of an organization is determined by how well and acceptable the internal control is and how it affects the financials of the companies. Senegal financial sector comprises 10 banks which are controlled by international financial conglomerates.

The microfinance institutions are rapidly increasing and reaching out to many households which include both small enterprises and informal businesses(Wong, 2012). The microfinance in Senegal include, savings and credit cooperatives, savings and credit associations and the semi-formal institutions which are financial NGOs and development projects with credit component. Due to the rampant growth of these institutions the central Bank of West Africa has had urgent legal framework which refer to its internal control system in managing them.

In this research paper, studies in the related field have been assessed in the literature review part. Research and methodology is followed by discussion and conclusion part.

\section{Literature Review}

Basically internal control is meant to help an organization achieve its mission, vision and goals.(Nuryanto \& Afiah, 2013). But never the less internal control systems helps the organization promote orderly, economically, efficient and effective operations and produce quality products and services consistent with the organization's mission. Internal control also safeguards company resources against loss which may occur due to waste, abuse, mismanagement, errors or even fraud. Internal control is also a tool that enables management directives in terms of law and regulations frameworks and also contracts. Relatively internal control of financial institutions helps in maintaining and developing reliable financial and management data which gives accurate and timely reports(Blanchard \& Galloway, 1994).

\section{Dimensions of Internal control in Financial Organizations}

Financial performance is said to directly impact the internal control of an institution. To focus on control environment, internal audit, risk assessment and control activities form the main components of an internal control system. The framework for internal control help microfinance institutions in managing their business in terms of regulations and policy(Raghunandan \& Rama, 1994). Frameworks for internal controls are factored by the processes affected by the board of directors, senior management and all levels of personnel. They are not entirely procedures or policies performed at certain point in time but rather continually operating at all levels within institutions. (Hitt, Hoskisson, Johnson, \& Moesel, 1996)

\section{Measurement of Financial performance of an organization}

Financial performance is the total assessment of an organization and it is measured in terms of market and accounting terms. Market measures reflect changes in stakeholder's returns on stock prices while the accounting measures are defined by residual terms or ratio terms. The accounting terms include, net income, after taxes, operating profits, residual income and economic value added this form measures by residual income. Those formed by ratio income are return on assets, return on investment and return on equity. (Indjejikian, Matějka, Merchant, \& Van der Stede, 2014)

\section{Theories on the effect of internal control and financial performance}

Effects of internal control and financial performance on microfinance institutions in Senegal formed the basis of study of this paper. Internal control has been defined in different research as the framework that is limited to Control environment, Risk assessment, Control activities Information and communication and Monitoring. For an institution to achieve on all this factors then it is essential to ensure that the internal control system is 
efficient enough to implement the above factors.(Gjerdrum \& Peter, 2011). The frameworks within any organization affect profitability when effectively implemented with good and strong internal control systems. There are various theories that interpret the internal control system and its effect on organization performance (Van Ryn \& Heaney, 1992). The various theoretical approaches which can be used to outline financial performance of organization are classified into; agency theory, institutional theory, system theory, transaction theory, stewardship theory and stakeholders theory. This paper will discuss on two theories that are related to microfinance institutions in Senegal.

\section{Agency theory}

In management and economics, the agency theory explains various relationships and areas of self interest in institutions. The theory usually explains how best to organize relationships in which one party is the principal determiner of the work and the other party is the agent who performs or makes decisions on behalf of the principal(Saraph, Benson, \& Schroeder, 1989) good auditing practices adopted by any organization usually enhance transparency in operations which project better financial performances. This is an assumption of the agency theory which states that the agency cost leads to design of audit practices that are applied by firms to mitigate any agency problems that may arise. Due to limited room for solving various challenges the decisions of the internal audits affect stakeholders which in turn do not give conclusive results. For this paper the agency theory will particularly integrate the involvement of internal controls and the functioning of microfinance. Agency theory may have some disadvantages which may relate to opportunism or self-interest of the agent. The theory also has a disadvantage in terms of information asymmetry where the principle and agent have access to different levels of information.

\section{Stakeholders Theory}

The theory identifies stakeholders and defines the performance outcomes as a satisfaction measure. The theory is based on organizational management and business ethics that seek to address values and morals in managing an organization. This theory classify the following in a way that employees, shareholders, suppliers and customers form the primary stakeholders and government, trade associations and political groups form the secondary stakeholders who have an indirect relationship with the firm (ALI, 2017). Stakeholder's theory critique that analylitics focus on how to resolve internal auditing challenges which is too narrow and shareholders are the only ones who make investments in the firms. For internal controls the decisions of stakeholders have an impact on all operations. Considering the importance of financial performance and internal control this theory adds knowledge on the findings on how stakeholders can benefit through strict adherence to internal control systems as an advantage to financial performance. (Saraph et al., 1989). This theory has multiple distinct aspects that mutually support each other in terms of description, instrument and normalcy(Phillips, Freeman, \& Wicks, 2003). The theory best explains character and behaviors of an organization thus including how these organizations are run. This theory is thus relevant to this study in that it shows how the microfinance are run. In knowing the activities progress of an organization then one is able to monitor and know the activities that lead to profits or losses. For any business to be successful it has to create value for its customers and people who matter to this organization. (Beasley, Chen, Nunez, \& Wright, 2006)

\section{Effect of Risk Assessment on Organization profitability}

Continuous assessing of the internal control system of an institution adversely affects its achievements and the goals of the institution. The assessment covers all risks facing the institution's departments addressing any new or previous uncontrolled risks. Risk assessment is the estimate of the likelihood and impact of internal control risks from internal and external sources. The main objective of understanding risk assessment for a microfinance institution is to help the institution be able to administer and administrate risks that occur in the institution. Every organization faces both internal and external risks which are prone to assessment (Amudo \& Inanga, 2009). Every organization internal control system should provide an assessment of the risks the organization is prone to. The organization identifies risks and then analyzes for the possibility of their effects. Once the risks have been identified its then the management responsibility to formulate an approach for risk management and decide on the internal control activities to be used to solve the risks and achieve the internal control goals and objectives. 
Ndiaye et al. / International Journal of Research in Business and Social Science,

Vol 8 No 2, 2019 ISSN: 2147-4486

\section{Effect of Control Procedures Organization profitability}

Control procedures are components of internal controls (Pany \& Whittington, 2001). They are usually described as activities which form policies and procedures that help the management to ensure certain directives are made in a proper manner. Control procedures in an organization involve; performance reviews, information processing, physical controls and segregation of duties in the organization. Control activities are important in supporting qualitative efficiency for organizations which carry out activities that focus on examination. For microfinance organizations this activities refer to achievements of their overall objectives of the control activity (Bostan \& Grosu, 2010). For control procedures it is expected effect on internal control and organization profitability leads to setting the fourth sub hypothesis of basic research systems which indicate that there is usually a significant influence of control activities on organization profitability of the microfinance institutions in Senegal

\section{Effect of control environment on Organization profitability}

Control environment in any organization sets a tone for the organization's influences of conscience of its people (Janvrin, Payne, Byrnes, Schneider, \& Curtis, 2012). Control environments form the overall structure and discipline of the internal control system. The control environment influences the integrity, ethical values, and competence of the management in the organization. The attitude of management should be geared towards improvement and values which form ethical business principles (Pany \& Whittington, 2001). When an organization practices the right values then it is motivated towards its profitability since workers will work very hard in the best interest of the company (Berona, 2005). Integrity and ethical values of an organization enhances creditworthiness of the stakeholders and more so leads to increase in investments in such an organization. For a microfinance institution it is necessary to cultivate competence, knowledge and skills which will lead to accomplishment of the organizations objectives. In Senegal it's clear that there is a significant influence of control environment on organizational profitability.

\section{Effect of Information and Communication on Organization profitability}

In the growing economy technology has become an essential tool for management in any organization. New technology is used by management to ensure the various business systems have a positive impact on the organization's profitability and success (Laudon \& Laudon, 2011). Information and communication technology in any organization facilitates the management with resources that help them make decisions on the current services and products that are relevant to the company. Selecting the appropriate products/services give the organization an advantage in the market that it's dealing with(Laudon \& Laudon, 2011). ICT is a very critical tool to internal control systems, it is usually in reference to proper functioning of all organization activities. Poor ICT infrastructures of any company may affect the organization from the management level to the lower staff hence making the organization prone to losses from all aspects. (Cescon, Costantini, \& Rossi, 2013). ICT is an essential tool in internal control systems and it significantly influences organization's profitability.

\section{Effect of Monitoring on Organization profitability(}

Monitoring is basically assessing any system or activity in an organization. The process of monitoring of organization's profitability is done by assessing different activities and operations of the organization. (Gjerdrum \& Peter, 2011). Monitoring is effective when done on timely basis and necessary actions done on time. Management monitoring is considered effective when the controls include considering whether the organization is operating as intended within the set conditions. Profitability of an organization can be monitored through assessing the organizations performance which may include the sale's person compliance with the company's sales policy (Sodan \& Hadank). Monitoring requires resources in order to achieve its objectives. An organization must be ready to provide adequate financial resources to enable it to achieve the monitoring process. Monitoring in many instances poses a positive effect on profitability of any organization. This is argued in the basis that when an organization monitors its internal control system, then it is able to detect failures in different activities hence correcting them in good time and improving towards great success which leads to high profit margins. (Demiroglu \& James, 2011)

\section{Research and Methodology}


This study utilized two sources of quantitative data. The first source contained data obtained from the managers and heads of internal audit units (IAU) of the registered and operational microfinance institutions in Senegal. The second source of quantitative data was from the financial statements as provided by those microfinance institutions which participated in the study. A questionnaire was used to collect the data from the sample of 110 microfinance institutions in Senegal sampled through proportionate stratified sampling. The measure of profitability of MFl's was ascertained from the financial statements and it included: The Earnings per Share (EPS), Return on Assets (ROA), profit Margin (PM), and Return on Equity (ROE). To avoid errors arising from common method biases (CMB), data was collected in waves. Caution was exercised to ensure that sampled MFI's were fully registered by the Central Bank of Senegal during the study period and that the firm should not have undergone any re-organizations in form of merger or acquisitions. Data collection was done through emailing of the questionnaires to the respondents well in advance and collection of the completed questionnaires was done by researcher herself. Before data collection both internal validity of the questionnaire and its reliability were tested. The questionnaire items were tested by use Cronbach Alpha and all items measuring Control Environment, Risk Assessment, Control Procedures, Control Activities and Monitoring were all above 0.8 implying high internal consistency. Data was analyzed both descriptively and inferentially using T-test and Ordinary Least square Regression. The model of the study is as follows:

\section{$P r=\beta_{0}+\beta 1 C E$ it $+\beta 2 R A$ it $+\beta 3 C A$ it $+\beta 4 I C$ it $+\beta 5 M$ it $+\alpha$}

\section{Where:}

Pr: Profitability

CE it: Control Environment for MFI / after time $t$,

RA it: Risk Assessment for MFI / after time $t$

CA it: Control Activities for MFI / after time $t$

IC it: Information and Communication for MFI / after time $t$

$\mathbf{M}$ it : Monitoring for MFI / after time $t$, and

$\boldsymbol{\alpha}$ is the error term associated with the measurement of the variables in the study and $\boldsymbol{\beta} 0$ the intercept of the study.

\section{Results and Findings}

All assumptions for the use of regression analysis were considered and included: The normality of the data which was ascertained by using a P.P plot and One-Sample Kolmogorov-Smirnov test for normality (K-S). The data was found to follow a normal distribution as shown in table 1 below.

Table 1: Test for Normality of Data.

\begin{tabular}{lllll}
\hline Variable & Mean & Std Deviation & K-S & Sig \\
\hline Earnings Per Share (ES) & 2.87 & 2.18 & 0.76 & 0.06 \\
Return On Assets (ROA) & 5.34 & 1.12 & 1.17 & 0.17 \\
Return on Equity (ROE) & 10.89 & 1.25 & 0.80 & 0.08 \\
Profit Margin (PM) & 0.40 & 0.75 & 1.71 & 0.23 \\
Control Environment & 4.19 & 0.62 & 0.90 & 0.10 \\
Risk Assessment & 4.19 & 0.66 & 0.83 & 0.07 \\
Control Procedures & 4.44 & 0.52 & 1.02 & 0.35 \\
Information and Com & 4.66 & 0.88 & 1.71 & 0.52 \\
Monitoring & 4.33 & 2.39 & 0.61 & 0.06 \\
\hline
\end{tabular}

From the table 1 above, the data appears normally distributed since the level of significance of most of the $\mathrm{K}-\mathrm{S}$ values were above 0.05 . The next step in the analysis was carrying out the descriptive statistics of the data. Table (2) shows some descriptive statistics about the internal control of the firms in our sample. It provides evidence about the compliance of the firms with the requirements of internal control according to Senegalese and global standards. Also, it shows that the degree of compliance with all components of internal control was of the set standard level. On a five point Likert scale, the minimum and maximum degree 
of compliance were 4.25 and 4.65 respectively, which is approximately equal to $82 \%$ and $91 \%$ respectively (as per extracts from the S-K test). These percentages of compliance imply that there is a very good internal control and a high degree of compliance with its requirements. From the same results, the t- values ranged from 37.29 to 56.6 with all significance values being less than 0.05 , implying that the degree of compliance with all internal control components is statistically significant. The results are summarized in the table below.

Table 2: Descriptive Statistics

\begin{tabular}{lllll}
\hline Variable & Mean & Std. Dev & T-Value & Sig \\
\hline Earnings Per Share (EPS) & 2.86 & 1.10 & 7.77 & 0.05 \\
Return On Assets (ROA) & 5.42 & 1.42 & 4.33 & 0.00 \\
Return on Equity (ROE) & 10.91 & 1.55 & 6.10 & 0.03 \\
Profit Margin (PM) & 0.40 & 0.75 & 3.16 & 0.00 \\
Control Environment & 4.25 & 0.61 & 41.84 & 0.01 \\
Risk Assessment & 4.26 & 0.67 & 36.28 & 0.00 \\
Control Procedures & 4.34 & 0.43 & 48.02 & 0.01 \\
Information and Communication & 4.56 & 2.26 & 55.92 & 0.04 \\
Monitoring & 4.25 & 0.38 & 53.23 & 0.00 \\
\hline
\end{tabular}

The degree of compliance with the control environment is approximately $86 \%$. The environment includes all issues necessary to help in achieving the basic objectives of internal control. For instance, the regulations of the Senegalese microfinance seem to give a high degree of priority to integrity and moral values and encourage those who are responsible for governance and all employees to give attention to such characteristics. The responses of all companies to the questionnaire show that they devote their efforts to create a control environment that helps in setting a solid ground for the other components of internal control. Control environments of these microfinance institutions concentrate on competence training and continuous learning and improvement which is accompanied by a flexible organizational structure that emphasizes on participation and human resources development. The table 2 above shows that the MFI's are keen in improving their risk assessment, control procedures, monitoring systems and the state of their information and communication. This in turn seems to influence the profitability of the organization as depicted by Earnings per Share (ES), Return on Assets (ROA), Return on Equity (ROE), and Profit Margin (PM).

Table (2) shows that on average, the EPS is 2.86 , the ROA is 5.42 , the ROE is 10.91 and profit margin is 0.40 . These indicators of profitability suggest that the Senegalese MFI's are profitable. Before interpreting the results of regression, a test of multicollinearity was done to ascertain whether the values of regression coefficients were inflated because of the correlation between the independent variables. The general rule of thumb is that Variance Inflation Factors (VIFs) exceeding 4 warrant further investigation, while VIFs exceeding 10 are signs of serious multicollinearity requiring correction (Kaplan, 1994 and Leahy, 2000). The results indicated no correlation amongst the predictors and hence they were fit in measuring the outcome variable (profitability). The results were not however reported as the normality of the data had not been earlier violated.

\section{Performance of MFI's in Senegal}

The outcome variable of the study was performance of MFl's in Senegal. This performance is annually declared by all MFl's licensed and recognized by the Central Bank of Senegal. The performance of MFI's in Senegal was estimated using ROA, ROE, PM, and EPS. The calculated mean value of each index for 10 years (2006-2016), in arrow is as shown below.

\begin{tabular}{|l|l|l|l|l|}
\hline Profitability Index & ROA & ROE & CPS & PM \\
\hline Mean score & 1.95 & 14.81 & 4.5 & 3.2 \\
\hline
\end{tabular}

By a rule of thumb, each index is above 1, implying that the most MFl's are profitable with the current internal control mechanism in place. This is consistent with the findings of Flamini, et al. (2009.) According to the 
above author, the average ROA in Sub-Saharan Africa, (SSA) was about 2\%. Thus, the average ROA of Senegal banks is about the average of that of the SSA.

\section{Results and Hypothesis Testing}

Four hypothesis guided the study. The hypothesis were tested through a regression analysis at $95 \%$ confidence interval. The hypothesis was accepted if the P-Value was above the significance level of 0.05 .

$\mathbf{H}_{1}$ : Internal control positively influences $\mathrm{ROE}$

$\mathbf{H}_{2}$ : Internal control positively influences $\mathrm{ROA}$

$\mathbf{H}_{3}$ : Internal control positively influences EPS

$\mathbf{H}_{4}$ : Internal control positively influences PM

\section{The effect of internal control on EPS}

The results of the correlation analysis between internal control and EPS showed that profitability of MFIs in Senegal (as measured by EPS) is correlated to internal control, which implies that the higher the compliance, the higher the EPS. However, this correlation between internal control and EPS is a mere existence of a positive relationship whose effect size has not been explained. On interpreting of the regression out, the adjusted $\mathrm{R}^{2}$ was equal to $11.5 \%$, which means that $11.5 \%$ of the variation in financial performance (measured by earnings per share (EPS), was attributed to internal control. This was supported by the Anova test in table 3 which reaffirmed a significant relationship between internal control and EPS $(p \leq 0.05)$. With respect to the effect size of each dimension of internal control on the profitability of the MFI's as measured by EPS, the table 3 below showed the effects sizes of each dimensions as indicated by the beta coefficients.

Table 3: Internal Control and EPS

\begin{tabular}{|c|c|c|c|c|c|}
\hline \multirow[t]{2}{*}{ Variable } & \multicolumn{2}{|c|}{ Unstandardized Coefficients } & Standardized & \multirow[t]{2}{*}{$T$} & \multirow{2}{*}{$\begin{array}{l}\text { Significance } \\
\text { Level. }\end{array}$} \\
\hline & B & Standard error & B & & \\
\hline Control Environment & 1.859 & 0.801 & 0.237 & 1.071 & 0.04 \\
\hline Risk Assessment & 1.112 & 0.682 & 0.662 & 2.872 & 0.05 \\
\hline Control Procedures & 1.346 & 1.145 & 0.463 & 2.237 & 0.02 \\
\hline $\begin{array}{l}\text { Information and } \\
\text { Communication }\end{array}$ & 0.741 & 1.263 & 0.352 & 2.271 & 0.01 \\
\hline Monitoring & 0.876 & 0.263 & 0.287 & 1.209 & 0.00 \\
\hline
\end{tabular}

From the results in table 3 above, all dimensions of internal control were positively and significantly associated with EPS with control procedures and control environment having the highest effect sizes. This findings concur with those of Cohen and Sayag (2010) who found out that internal control with strengthened aspects of internal control systems and procedures enables the organization to minimize fraud and improve the ESP aspects of performance. Since all dimensions of internal control were correlated with ESP, a composite variable was generated from the three dimensions and abbreviated as 'internal control'. On establishing a relationship between this composite variable and ESP, the composite variable was found to be positively associated with ESP $(p<0.05)$, and following this, hypothesis that internal control was positively associated with ESP was accepted.

\section{The effect of internal control on ROA}

The results of the correlational analysis between internal control and ROA shows that profitability of MFIs in Senegal (as measured by ROA) is correlated to internal control which implies that the higher the compliance, the higher the ROA. To estimate the effect size of each dimension on ROA, a multiple regression analysis was carried out with both standardized and unstandardized variables. The results of the regression analysis 
showed that adjusted R2 is equal to $42 \%$, which means that $42 \%$ of the variation in financial performance (measured by return on assets (ROA)) can be attributed to internal control. The effect sizes of each dimension of internal control on ROA was estimated from the beta coefficients and the results are as shown in table 4 below:

Table 4: Internal Control and ROA

\begin{tabular}{llclll}
\hline Variable & \multicolumn{2}{l}{ Unstandardized Coefficients } & $\begin{array}{l}\text { Standardized } \\
\text { Coefficients }\end{array}$ & $\mathrm{T}$ & $\begin{array}{l}\text { Significance } \\
\text { Level. }\end{array}$ \\
& $\mathrm{B}$ & Standard error & $\beta$ & & \\
\hline Control Environment & 1.456 & 0.702 & 0.231 & 3.082 & 0.01 \\
Risk Assessment & 2.112 & 1.682 & 0.562 & 2.373 & 0.00 \\
Control Procedures & 0.532 & 1.845 & 0.562 & 2.638 & 0.03 \\
Information and & .471 & 1.263 & 0.652 & 2.362 & 0.02 \\
Communication & & & & & \\
Monitoring & 0.773 & 0.361 & 0.387 & 2.307 & 0.01 \\
\hline
\end{tabular}

The findings from the table 4 above indicates that all dimensions of internal control were significantly and positively associated to ROA with control environment and risk assessment having a high impact size on ROA than the rest. To test the hypothesis that internal control positively associated with ROA, a composite variable representing all dimensions of internal control was generated and abbreviated as 'internal control'. A regression analysis was run between the composite variable and ROA, and the results interpreted. The regression output indicated a positive and significant relation between the 'internal control' variable and ROA $(p<0.05)$, with an adjusted $R^{2}$ of $41 \%$ implying that internal control explained $41 \% \%$ of variance in $R O A$ in MFI's in Senegal. As such the hypothesis that internal control positively influenced ROA was accepted.

\section{The effect of internal control on ROE}

The analysis results between internal control and ROE shows that profitability of MFIs in Senegal (as measured by ROE) is correlated to internal control. This implies that the higher the compliance, the higher the ROE. The coefficients in regression analysis between the various components of internal control and ROE indicated that the components were all correlated to ROE. The adjusted $\mathrm{R}^{2}$ was equal to $13.54 \%$, which means that $13.54 \%$ of the variation in financial performance (ROE), was attributed to internal control. The results are as shown in the table below 5 below:

Table 5: Internal Control and ROE

\begin{tabular}{|c|c|c|c|c|c|}
\hline \multirow[t]{2}{*}{ Variable } & \multicolumn{2}{|c|}{ Unstandardized Coefficients } & \multirow{2}{*}{$\begin{array}{c}\text { Standardized } \\
\text { Coefficients } \\
\text { B }\end{array}$} & \multirow[t]{2}{*}{$\mathrm{T}$} & \multirow{2}{*}{$\begin{array}{l}\text { Significance } \\
\text { Level. }\end{array}$} \\
\hline & B & Standard error & & & \\
\hline Control Environment & 1.231 & 0.635 & 0.301 & 1.082 & 0.02 \\
\hline Risk Assessment & 1.086 & 1.187 & 0.308 & 2.081 & 0.00 \\
\hline Control Procedures & 0.234 & 1.287 & 0.423 & 1.229 & 0.00 \\
\hline $\begin{array}{l}\text { Information and } \\
\text { Communication }\end{array}$ & .287 & 1.235 & 0.231 & 1.387 & 0.04 \\
\hline Monitoring & 0.486 & 0.287 & 0.352 & 2.105 & 0.03 \\
\hline
\end{tabular}

The results in table 5 above indicate that all the components of internal control were positively associated to ROE with control environment and risk assessment (just like in previous indices of profitability) having a higher effect size on ROA than the rest. To test the hypothesis that internal control positively influences ROA was ascertained using a composite variable representing all the components of internal control and regressed with ROA. The regression analysis showed that internal control was positively and significantly associated with ROA $(p<0.05)$ hence the hypothesis was accepted. $R^{2}$ of regression analysis was 0.39 , implying that $39 \%$ variance in ROA was explained by internal control status of MFI's in Senegal. This findings concur with those of (Vijayakumar \& Nagaraja, 2012) whose study found out that internal control positively influences performance of organizations. 


\section{The effect of internal control on PM}

The results of the correlation analysis between internal control and EPS showed that profitability of MFIs in Senegal (as measured by PM) is correlated to internal control, which implies that the higher the compliance, the higher the PM. However, this correlation between internal control and PM is a mere existence of a positive relationship whose effect size has not been explained. On interpreting of the regression out, the adjusted $\mathrm{R}^{2}$ was equal to $9.5 \%$, which means that $9.5 \%$ of the variation in financial performance (PM), was attributed to internal control. The results of the regression analysis between the various components of internal control and PM is shown by the beta coefficients in table 6 below:

Table 6: Internal Control and PM

\begin{tabular}{|c|c|c|c|c|c|}
\hline \multirow[t]{2}{*}{ Variable } & \multicolumn{2}{|c|}{ Unstandardized Coefficients } & \multirow{2}{*}{$\begin{array}{c}\text { Standardized } \\
\text { Coefficients } \\
\text { B }\end{array}$} & \multirow[t]{2}{*}{$T$} & \multirow{2}{*}{$\begin{array}{l}\text { Significance } \\
\text { Level. }\end{array}$} \\
\hline & B & Standard error & & & \\
\hline Control Environment & 1.186 & 0.036 & 0.202 & 1.112 & 0.00 \\
\hline Risk Assessment & 1.121 & 1.028 & 0.253 & 2.120 & 0.00 \\
\hline Control Procedures & 0.026 & 0.175 & 0.321 & 1.219 & 0.01 \\
\hline $\begin{array}{l}\text { Information and } \\
\text { Communication }\end{array}$ & 1.036 & 1.121 & 0.065 & 1.270 & 0.02 \\
\hline Monitoring & 0.220 & 0.223 & 0.322 & 1.202 & 0.00 \\
\hline
\end{tabular}

The results in table 6 above indicate that all the components of internal control were positively associated to ROE. To test the hypothesis that internal control positively influences PM was ascertained using a composite variable representing all the components of internal control and regressed with ROA. The regression analysis between the dimensions of internal control and PM showed that internal control was positively and significantly associated with PM $(p<0.05)$ hence the stated hypothesis that internal control positively and significantly related to $P M$ was accepted with the $R^{2}$ of 0.42 , implying that $42 \%$ variance in $P M$ was explained by internal control status of MFI's in Senegal. This findings concur with those of (Beneish, Billings, \& Hodder, 2008) who intimated that internal control with proper systems in risk management and financial control will increase sustainable profitability of the organizations.

\section{Conclusions}

The overall objective of this study was to examine the effects of internal control mechanisms on the performance of microfinance institutions in Senegal. The main indicator of performance was the profitability of MFI's. Fromm the stakeholders theory(Vijayakumar \& Nagaraja, 2012), stakeholders deserve returns on their investments and as such financial institutions managing stakes on behalf of them must declare the profits and losses annually and justify the state of the performance of the institutions in an annual general meeting for the shareholders. Its by doing so that the shareholders will be able to make viable decisions concerning the internal control mechanisms which can increase profitability of such institutions. Profitability was measured by four indices namely: EPS, PM, ROA, AND ROE. To achieve these objectives ten years panel data for 110 microfinance institutions in Senegal sampled through proportionate stratified sampling and analyzed using linear multiple regression model. It was found that bank specific factors significantly affect the profitability of MFI's. The analysis shows that the effect of internal control components on ROA, Eps, PM and ROE was positive and significant. However, the implementation of internal control activities is not reasonably effective at all times and in all directions. We have to remember that regardless of the power of internal control systems there are some limitations for any internal control system that may prevent it from achieving a high degree of effectiveness, that is, we receive only reasonable assurance of the achievement of internal control objectives (Elder et al. 2012).

Based on the results of the study the researchers would recommend the managers of shareholding companies to concentrate on internal control systems with all their components, to maximizing the wellbeing of their entities. Even when we found that there is a high degree of compliance with all components of internal control, we found that the relationship between profitability and control environment, information and 
communication and monitoring is positive but insignificant. The insignificant relationship between internal control and some measures of profitability may direct our attention to us being careful of the proper implementation of internal control. That is the compliance with internal control requirements may not lead to effective implementation. We may have a proper designed internal control system but not properly implementation(Odhiambo, 2009).

The other idea we need to consider is that there are many other factors that may influence performance and result in reducing or improving the power of internal control in persuading the objectives of the organization. Regarding this issue we suggest that the Senegal Microfinance institutions should review the effectiveness of the implementation of internal control requirements, especially those related to control environment, information and communication and monitoring. Finally, we can argue that the results of our study would also suggest new evidence of the relationship between internal control and profitability in a West African environment, which may suggest that there is a need to expand this study using other methodologies to delve into the depths and understand this phenomenon within its context. That is, the results, which are to some extent contradictory to some previous research findings, may point to the fact that there are some contextual factors preventing internal control from promoting performance in all instances and regarding all issues. The impact of internal control on organizations' performance may vary depending on organization specific factors, including size and the nature of its activities besides the macro factors. This study therefore recommends that MFI's in Senegal should strengthen their internal control systems especially those on risk management and control environment so as to increase their profitability.

\section{Compliance with Ethical Standards:}

Ethical approval for this study was granted from the Hefei University of Science and Technology as well as the Senegal Research Council. All procedures performed in this study involving human participants were in accordance with the ethical standards of the institution and relevant permission was granted before collecting data from the participants.

Informed consent was obtained from all the participants in this study. All the authors declare that they have no conflict of interest

\section{References}

Ali, s. I. (2017). The effect of internal audit on financial performance of microfinance institutions in kenya.

Amudo, A., \& Inanga, E. L. (2009). Evaluation of internal control systems: A case study from Uganda. International Research Journal of Finance and Economics, 27(1), 124-144.

Beasley, M., Chen, A., Nunez, K., \& Wright, L. (2006). Working hand in hand: Balanced scorecards and enterprise risk management. Strategic finance, 87(9), 49.

Beneish, M. D., Billings, M. B., \& Hodder, L. D. (2008). Internal control weaknesses and information uncertainty. The accounting review, 83(3), 665-703.

Berona, D. (2005). Tilting at windmills: A novel of Cervantes and the errant knight: Bowker Magazine Group Cahners Magazine Division 249 W 17th St, New York, NY 10011 USA.

Blanchard, R., \& Galloway, R. J. I. J. o. S. I. M. (1994). Quality in retail banking. 5(4), 5-23.

Bostan, I., \& Grosu, V. (2010). The Role of Internal Audit in Optimization of Corporate Governance at the Groups of Companies. Theoretical \& Applied Economics, 17(2).

Cescon, F., Costantini, A., \& Rossi, G. (2013). The influence of business strategy and ownership on management accounting innovations and risk management techniques: An empirical analysis in large manufacturing companies in Italy. Udine, Italy: University of Udine, Department of Economics and Statistics.

Cohen, A., \& Sayag, G. (2010). The effectiveness of internal auditing: an empirical examination of its determinants in Israeli organisations. Australian Accounting Review, 20(3), 296-307. 
Demiroglu, C., \& James, C. (2011). The use of bank lines of credit in corporate liquidity management: A review of empirical evidence. Journal of Banking \& Finance, 35(4), 775-782.

Gjerdrum, D., \& Peter, M. (2011). The new international standard on the practice of risk management-A comparison of ISO 31000: 2009 and the COSO ERM framework. Risk management, 31(2), 8-13.

Hitt, M. A., Hoskisson, R. E., Johnson, R. A., \& Moesel, D. D. J. A. o. m. j. (1996). The market for corporate control and firm innovation. 39(5), 1084-1119.

Indjejikian, R. J., Matějka, M., Merchant, K. A., \& Van der Stede, W. A. J. T. A. R. (2014). Earnings targets and annual bonus incentives. 89(4), 1227-1258.

Janvrin, D. J., Payne, E. A., Byrnes, P., Schneider, G. P., \& Curtis, M. B. (2012). The updated COSO Internal Control-Integrated Framework: Recommendations and opportunities for future research. Journal of Information Systems, 26(2), 189-213.

Kieso, D. E., Weygandt, J. J., \& Warfield, T. D. (2010). Intermediate accounting: IFRS edition (Vol. 2): John Wiley \& Sons.

Laudon, K. C., \& Laudon, J. P. (2011). Essentials of management information systems: Pearson Upper Saddle River.

McPeak, D., Pincus, K. V., \& Sundem, G. L. J. I. i. A. E. (2012). The international accounting education standards board: influencing global accounting education. 27(3), 743-750.

Nuryanto, M., \& Afiah, N. N. J. W. R. o. B. R. (2013). The impact of apparatus competence, information technology utilization and internal control on financial statement quality (study on local government of Jakarta province-Indonesia). 3(4), 157-171.

Odhiambo, N. M. (2009). Interest rate reforms, financial deepening and economic growth in Kenya: an empirical investigation. The Journal of Developing Areas, 295-313.

Pany, K. J., \& Whittington, O. R. (2001). Research implications of the Auditing Standard Board's current agenda. Accounting Horizons, 15(4), 401-411.

Phillips, R., Freeman, R. E., \& Wicks, A. C. (2003). What stakeholder theory is not. Business ethics quarterly, 13(4), 479-502.

Raghunandan, K., \& Rama, D. V. J. I. A. (1994). Management reports after COSO. 51(4), 54-60.

Saraph, J. V., Benson, P. G., \& Schroeder, R. G. J. D. s. (1989). An instrument for measuring the critical factors of quality management. 20(4), 810-829.

Sodan, U. D. H., \& Hadank, B. Zur demokratischen Legitimation des Gemeinsamen Bundesausschusses.

Van Ryn, M., \& Heaney, C. A. (1992). What's the use of theory? Health Education Quarterly, 19(3), 315-330.

Vijayakumar, A., \& Nagaraja, N. (2012). Internal Control Systems: Effectiveness of Internal Audit in Risk Management at Public Sector Enterprises. BVIMR Management Edge, 5(1).

Wong, S. J. W. B., Washington, DC. (2012). What have been the impacts of World Bank Community-Driven Development Programs? CDD impact evaluation review and operational and research implications. 